\title{
Front Matter: Volume 6667
}

, "Front Matter: Volume 6667," Proc. SPIE 6667, Current Developments in Lens Design and Optical Engineering VIII, 666701 (25 September 2007); doi: 10.1117/12.774161

SPIE Event: Optical Engineering + Applications, 2007, San Diego, California, United SPIE. States 


\section{PROCEEDINGS OF SPIE}

\section{Current Developments in Lens \\ Design and Optical Engineering VIII}

Pantazis Z. Mouroulis

Warren J. Smith

R. Barry Johnson

Editors

27 August 2007

San Diego, California, USA

Sponsored and Published by

SPIE 
The papers included in this volume were part of the technical conference cited on the cover and title page. Papers were selected and subject to review by the editors and conference program committee. Some conference presentations may not be available for publication. The papers published in these proceedings reflect the work and thoughts of the authors and are published herein as submitted. The publisher is not responsible for the validity of the information or for any outcomes resulting from reliance thereon.

Please use the following format to cite material from this book:

Author(s), "Title of Paper," in Current Developments in Lens Design and Optical Engineering VIII, edited by Pantazis Z. Mouroulis, Warren J. Smith, R. Barry Johnson, Proceedings of SPIE Vol. 6667 (SPIE, Bellingham, WA, 2007) Article CID Number.

ISSN 0277-786X

ISBN 9780819468154

Published by

SPIE

P.O. Box 10, Bellingham, Washington $98227-0010$ USA

Telephone +1 3606763290 (Pacific Time) · Fax +1 3606471445

SPIE.org

Copyright (c) 2007, Society of Photo-Optical Instrumentation Engineers

Copying of material in this book for internal or personal use, or for the internal or personal use of specific clients, beyond the fair use provisions granted by the U.S. Copyright Law is authorized by SPIE subject to payment of copying fees. The Transactional Reporting Service base fee for this volume is $\$ 18.00$ per article (or portion thereof), which should be paid directly to the Copyright Clearance Center (CCC), 222 Rosewood Drive, Danvers, MA 01923. Payment may also be made electronically through CCC Online at copyright.com. Other copying for republication, resale, advertising or promotion, or any form of systematic or multiple reproduction of any material in this book is prohibited except with permission in writing from the publisher. The CCC fee code is $0277-786 \mathrm{X} / 07 / \$ 18.00$.

Printed in the United States of America.

Publication of record for individual papers is online in the SPIE Digital Library.

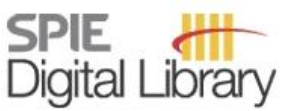

SPIEDigitalLibrary.org

Paper Numbering: Proceedings of SPIE follow an e-First publication model, with papers published first online and then in print and on CD-ROM. Papers are published as they are submitted and meet publication criteria. A unique, consistent, permanent citation identifier (CID) number is assigned to each article at the time of the first publication. Utilization of CIDs allows articles to be fully citable as soon they are published online, and connects the same identifier to all online, print, and electronic versions of the publication. SPIE uses a six-digit CID article numbering system in which:

- The first four digits correspond to the SPIE volume number.

- The last two digits indicate publication order within the volume using a Base 36 numbering system employing both numerals and letters. These two-number sets start with $00,01,02,03,04,05$, 06, 07, 08, 09, OA, OB ... 0Z, followed by 10-1Z, 20-2Z, etc.

The CID number appears on each page of the manuscript. The complete citation is used on the first page, and an abbreviated version on subsequent pages. Numbers in the index correspond to the last two digits of the six-digit CID number. 


\section{Contents}

vii Conference Committee

\section{SESSION 1 LENS DESIGN AND APPLICATIONS}

666703 New generation of high-resolution panoramic lenses [6667-02]

S. Thibault, ImmerVision (Canada)

666704 Design and analysis of a diffractive astigmatic lens for DVD pickup [6667-03]

W.-J. Chen, Univ. of Minnesota, Twin Cities (USA); C.-H. Chen, National Tsing Hua Univ. (Taiwan)

666705 Large-format telecentric lens [6667-04]

H. Bai, S. P. Sadoulet, Edmund Optics Inc. (USA)

666706 Rear landscape on steroids [6667-05]

P. Mouroulis, Jet Propulsion Lab. (USA)

666707 Optical encoder based on a nondiffractive beam [6667-06]

A. Lutenberg, F. Perez Quintián, M. A. Rebollo, Univ. de Buenos Aires (Argentina)

\section{SESSION 2 ABERRATION THEORY AND DESIGN}

666708 Practical guide to saddle-point construction in lens design (Invited Paper) [6667-07]

F. Bociort, M. van Turnhout, O. Marinescu, Delft Univ. of Technology (Netherlands)

666709 Predictability and unpredictability in optical system optimization [6667-08]

M. van Turnhout, F. Bociort, Delft Univ. of Technology (Netherlands)

6667 OA Some properties of Mertz type aspheric surfaces [6667-09]

T. B. Andersen, Lockheed Martin Space Systems Co. (USA)

$6667 \mathrm{OB}$ Third order aberration solution using aberration polynomials for a general zoom lens design [6667-10]

H. K. An, Univ. of Alabama Huntsville (USA); J. L. Rayces, J. L. Rayces Consulting (USA);

P. J. Reardon, Univ. of Alabama Huntsville (USA)

\section{SESSION 3 SYSTEM MODELING I}

6667 OC Vision multiplexing: an optical engineering concept for low-vision aids (Invited Paper) [6667-11]

E. Peli, Schepens Eye Research Institute, Harvard Medical School (USA) 
6667 OD Bi-centenary of successes of Fourier theorem: its power and limitations in optical system designs (Invited Paper) [6667-18]

C. Roychoudhuri, Univ. of Connecticut (USA) and Femto Macro Continuum Storrs (USA)

6667 OE Modeling of polychromatic MTF losses due to secondary effects in diffractive lenses [6667-12]

M. D. Thorpe, R. P. Jonas, S. Szapiel, ELCAN Optical Technologies (Canada)

6667 OF Scene-based sensor modeling using optical design software [6667-13]

J. Fisher, Brandywine Optics, Inc. (USA)

$66670 G$ Spectral response evaluation and computation for pushbroom imaging spectrometers [6667-14]

P. Mouroulis, R. O. Green, Jet Propulsion Lab. (USA)

\section{SESSION 4 SYSTEM MODELING II}

$6667 \mathrm{OH} \quad$ Polarization vortices in optical design (Invited Paper) [6667-15]

T. G. Brown, The Institute of Optics, Univ. of Rochester (USA)

6667 Ol Focal splitting and optical vortex structure induced by stress birefringence [6667-16]

A. K. Spilman, A. M. Beckley, T. G. Brown, The Institute of Optics, Univ. of Rochester (USA)

6667 0J Analysis of stray light in most complex situations [6667-17]

J.-C. Perrin, J.C.P.C.-Le Buet (France)

\section{POSTER SESSION}

6667 OK Aplanatic hybrid lenses [6667-19]

O. Garcia-Liévanos, S. Vázquez-Montiel, Instituto Nacional de Astrofísica, Óptica y Electrónica (Mexico)

$6667 \mathrm{OL}$ Mechanical design and analysis of a variable focal length lens [6667-20]

J. González-García, V. M. Cruz-Martínez, Á. J. Mendoza-Jasso, A. Santiago-Alvarado, Univ. Tecnológica de la Mixteca (Mexico); S. Vázquez-Montiel, Instituto Nacional de Astrofísica, Óptica y Electrónica (Mexico); J. A. Rayas-Alvarez, Ctr. de Investigaciones en Óptica (Mexico); J. Castro-Ramos, Instituto Nacional de Astrofísica, Óptica y Electrónica (Mexico)

6667 OM Estimating the factors restricting potential dynamic range in the optical scheme of acousto-optical spectrometer for the Mexican Large Millimeter Telescope [6667-21] A. S. Shcherbakov, S. E. Balderas Mata, D. Sanchez Lucero, National Institute for Astrophysics, Optics \& Electronics (Mexico)

666700 Studies of the manufacturability of the HOE included in objective of BD/DVD combined optical pick-up head according to the objective lens glass type [6667-23]

N. V. Lisitsyna, Bauman Moscow State Technical Univ. (Russia)

6667 OP A compact and cost effective design for cell phone zoom lens [6667-25]

C.-W. Chang, Industrial Technology Research Institute (Taiwan); C.-C. Wu, EFUN Technology Co., Ltd. (Taiwan) 
$66670 Q \quad X$ Xrace: a new ray tracing tool for simulation of $x$-ray beamlines at ANKA [6667-26] S. Trabelsi-Baver, Karlsruhe Research Ctr. (Germany); M. Baver, Precision Motors Deutsche Minebea GmbH (Germany); R. Steininger, T. Baumbach, Karlsruhe Research Ctr. (Germany)

6667 OR Optical design method for high zoom ratio lens with liquid lens and digital signal processing [6667-27]

C.-C. Hu, Industrial Technology Research Institute-South (Taiwan); Y. C. Fang, National Kaohsiung Univ. of Science and Technology (Taiwan); C.-M. Tsai, Kun Shan Univ. (Taiwan); H.-C. Lin, National Kaohsiung Univ. of Science and Technology (Taiwan); H.-W. Su, Industrial Technology Research Institute-South (Taiwan); Y.-C. Lin, National Kaohsiung Univ. of Science and Technology (Taiwan)

Author Index 
Downloaded From: https://www.spiedigitallibrary.org/conference-proceedings-of-spie on 26 Apr 2023

Terms of Use: https://www.spiedigitallibrary.org/terms-of-use 


\title{
Conference Committee
}

\author{
Conference Chairs \\ Pantazis Z. Mouroulis, Jet Propulsion Laboratory (USA) \\ Warren J. Smith, Rockwell Collins Optronics (USA) \\ R. Barry Johnson, PanTechne Corporation (USA) \\ Program Committee
}

Florian Bociort, Technische Universiteit Delft (Netherlands)

Apostolos Deslis, InPhase Technologies (USA)

Robert E. Fischer, OPTICS 1, Inc. (USA)

Virendra N. Mahajan, The Aerospace Corporation (USA)

Simon Thibault, ImmerVision (Canada)

Daniel W. Wilson, Jet Propulsion Laboratory (USA)

Andrew P. Wood, QIOPTIQ (United Kingdom)

James M. Zavislan, University of Rochester (USA)

Session Chairs

1 Lens Design and Applications

Virendra N. Mahajan, The Aerospace Corporation (USA)

2 Aberration Theory and Design

Simon Thibault, ImmerVision (Canada)

3 System Modeling I

Simon Thibault, ImmerVision (Canada)

$4 \quad$ System Modeling II

Julie Bentley, Corning Tropel Corporation (USA) 
Downloaded From: https://www.spiedigitallibrary.org/conference-proceedings-of-spie on 26 Apr 2023

Terms of Use: https://www.spiedigitallibrary.org/terms-of-use 